\title{
Seagrass-mediated phosphorus and iron solubilization in tropical sediments
}

Brodersen, Kasper Elgetti; Koren, Klaus; Mosshammer, Maria; Ralph, Peter J.; Kühl, Michael; Santner, Jakob

Published in:

Environmental Science \& Technology

DOI:

10.1021/acs.est.7b03878

Publication date:

2017

Document version

Publisher's PDF, also known as Version of record

Document license:

CC BY

Citation for published version (APA):

Brodersen, K. E., Koren, K., Mosshammer, M., Ralph, P. J., Kühl, M., \& Santner, J. (2017). Seagrass-mediated phosphorus and iron solubilization in tropical sediments. Environmental Science \& Technology, 51(24), 1415514163. https://doi.org/10.1021/acs.est.7b03878 


\title{
Seagrass-Mediated Phosphorus and Iron Solubilization in Tropical Sediments
}

\author{
Kasper Elgetti Brodersen, ${ }^{\dagger, \ddagger}$ Klaus Koren, ${ }^{\ddagger}$ Maria Moßhammer, ${ }^{\ddagger}$ Peter J. Ralph, ${ }^{\dagger}$ Michael Kühl, ${ }^{*},{ }^{\dagger}$, \\ and Jakob Santner*,, ,
}

${ }^{\dagger}$ Climate Change Cluster, Faculty of Science, University of Technology Sydney (UTS), Sydney 2007, New South Wales, Australia

${ }^{\ddagger}$ Marine Biological Section, Department of Biology, University of Copenhagen, DK-3000 Helsingør, Denmark

${ }^{\S}$ Division of Agronomy, Department of Crop SciencesUniversity of Natural Resources and Life Sciences, Vienna, 3430 Tulln an der Donau, Austria

"Rhizosphere Ecology and Biogeochemistry Group, Institute of Soil Research, Department of Forest and Soil Sciences, University of Natural Resources and Life Sciences, Vienna, 3430 Tulln an der Donau, Austria

\section{Supporting Information}

ABSTRACT: Tropical seagrasses are nutrient-limited owing to the strong phosphorus fixation capacity of carbonate-rich sediments, yet they form densely vegetated, multispecies meadows in oligotrophic tropical waters. Using a novel combination of high-resolution, two-dimensional chemical imaging of $\mathrm{O}_{2}, \mathrm{pH}$, iron, sulfide, calcium, and phosphorus, we found that tropical seagrasses are able to mobilize the essential nutrients iron and phosphorus in their rhizosphere via multiple biogeochemical pathways. We show that tropical seagrasses mobilize phosphorus and iron within their rhizosphere via plant-induced local acidification, leading to dissolution of carbonates and release of phosphate, and via local stimulation of microbial sulfide production, causing reduction of insoluble $\mathrm{Fe}$ (III) oxyhydroxides to dissolved $\mathrm{Fe}$ (II) with concomitant phosphate release into the rhizosphere porewater. These nutrient mobilization mechanisms have a direct link to seagrass-derived radial $\mathrm{O}_{2}$ loss and secretion of dissolved organic carbon from the below-ground tissue into the rhizosphere. Our demonstration of seagrass-derived rhizospheric phosphorus and iron mobilization explains why seagrasses are widely distributed in oligotrophic tropical waters.

\section{INTRODUCTION}

Seagrasses are found in coastal waters worldwide except Antarctica, and seagrass meadows are important high-value ecosystems ${ }^{1,2}$ providing numerous ecosystem services in terms of high biodiversity, ${ }^{3}$ enhanced sediment carbon sequestration, ${ }^{4}$ and coastal zone protection against erosion. ${ }^{5}$ In tropical sedimentary environments, strong fixation of phosphorus in the prevailing carbonate-rich sediments, ${ }^{6-9}$ and adsorption of phosphorus to insoluble iron(Fe)(III) oxyhydroxides ${ }^{10}$ lead to strong nutrient limitation. Phosphorus deficiency can negatively affect several plant processes such as energy transfer, photosynthesis, respiration, enzyme regulation, and the synthesis of nucleic acids and membranes. ${ }^{11}$ Phosphorus is mainly absorbed through the rhizome and roots of seagrasses, ${ }^{12}$ and despite very low (nM) free phosphorus levels in pore waters of carbonaterich sediments in oligotrophic waters, seagrasses thrive and sustain high primary production forming extensive meadows in such tropical habitats. ${ }^{13}$ Seagrasses growing in carbonate-rich sediments also suffer from $\mathrm{Fe}$ deficiency ${ }^{14}$ with potentially adverse effects on photopigment concentrations in leaves. Tropical seagrass species, such as Cymodocea sp., Halodule sp.,
Halophila sp., and Thalassia sp., thus seem to have evolved phosphorus, and possibly iron, acquisition mechanisms to support their nutrient requirements, but experimental demonstration of plant-mediated nutrient mobilization from sediments is hitherto lacking. ${ }^{15}$

It has been suggested that seagrass-generated rhizospheric phosphorus solubilization is linked to (i) the release of organic acids from roots (or organic acids derived by fermentation of root/rhizome exudates, such as sucrose) $)^{16}$ and (ii) plantderived decreases of the rhizosphere $\mathrm{pH}$ as a result of root/ rhizome-released acidic substances and/or radial $\mathrm{O}_{2}$ loss (ROL), which leads to acidification through the oxidation of sediment-produced sulfide. ${ }^{17,18}$ Such rhizosphere acidification may result in carbonate dissolution and concomitant phosphate release into the porewater. Seagrasses mainly leak $\mathrm{O}_{2}$ from the root/shoot junctions and the root apical meristem area close to

Received: July 28, 2017

Revised: October 17, 2017

Accepted: November 17, 2017

Published: November 17, 2017 
the root-tips, ${ }^{17,19,20}$ whereas mature parts of the roots possess barriers to ROL. ${ }^{21}$ Barriers to ROL likely improve the efficiency of long-distance gas transport within the aerenchyma and thereby improve the internal plant aeration. ${ }^{22}$ The rate of ROL from the below-ground tissue is thus largely determined by the internal $\mathrm{O}_{2}$ concentration gradient, where the leaves functions as $\mathrm{O}_{2}$ source and the below-ground tissue as $\mathrm{O}_{2}$ sink. ${ }^{23} \mathrm{ROL}$ from the below-ground tissue is higher during active leaf photosynthesis as compared to during night-time, where seagrasses depend on the $\mathrm{O}_{2}$ availability in the ambient water. $^{17,19,24}$

Seagrasses also secrete dissolved organic carbon (DOC) into their rhizosphere as root/rhizome exudates, ${ }^{25}$ which fuel the rhizospheric microbial community ${ }^{26}$ and have been shown to stimulate $\mathrm{N}_{2}$ fixation in the seagrass rhizosphere via sulfatereducing diazotrophs, thus relieving nitrogen limitation. ${ }^{27}$ Sulfate-reducing bacteria (SRB) are highly abundant in seagrass-inhabited sediments, ${ }^{28,29}$ where sulfate reduction rates have been shown to increase during photosynthesis. ${ }^{30,31}$ SRB form hydrogen sulfide $\left(\mathrm{H}_{2} \mathrm{~S}\right)$, which is toxic to seagrasses. ${ }^{32} \mathrm{H}_{2} \mathrm{~S}$ intrusion into the below-ground aerenchymal tissue has previously been reported, especially during unfavorable environmental conditions such as water-column hypoxia, high water-column turbidity, and sedimentation onto seagrass leaves impeding the internal plant aeration. ${ }^{33,34}$ The ability of seagrasses to aerate the rhizosphere and alter the rhizospheric biogeochemical processes and geochemical conditions is thus critical for their survival. SRB may play multiple roles in tropical sediments. It has been proposed that high rhizospheric $\mathrm{H}_{2} \mathrm{~S}$ concentrations can reduce insoluble $\mathrm{Fe}(\mathrm{III})$ oxyhydroxides to dissolved $\mathrm{Fe}(\mathrm{II})$, co-dissolving $\mathrm{Fe}(\mathrm{III})$ oxyhydroxide-bound phosphate, ${ }^{10}$ in addition to the positive effect that $\mathrm{N}_{2}$-fixing $\mathrm{SRB}$ appear to have on the porewater nitrogen availability. In this way, SRB may have both beneficial and detrimental effects on seagrass health. Moreover, root/ rhizome exudates may also directly stimulate microbiological $\mathrm{Fe}(\mathrm{III})$ reduction, thus further supporting the seagrasses' $\mathrm{Fe}$ demand. However, the mentioned plant-mediated phosphorus and iron mobilization mechanisms remain speculative and have never been demonstrated directly in the seagrass rhizosphere.

Using a novel combination of high-resolution in situ chemical imaging methods (see detailed description in the Supporting Information, notes S1 and Figure S1-S6), we now present the first experimental demonstration of seagrass-derived rhizospheric phosphorus and iron mobilization, thus resolving how tropical seagrasses thrive in nutrient-poor carbonate sediments. The underlying hypotheses were (i) that seagrasses can actively stimulate sulfide production in the rhizosphere leading to reduction of insoluble $\mathrm{Fe}$ (III) oxyhydroxides to $\mathrm{Fe}(\mathrm{II})$, and (ii) that local acidification of the rhizosphere via ROL (potentially supported by $\mathrm{Fe}(\mathrm{II})$ oxidation) results in concomitant dissolution of carbonates and thus releases sediment-bound phosphorus to the porewater. Moreover, diel cycles of ROL may favor microbiological $\mathrm{Fe}(\mathrm{III})$ and sulfate reduction in the night, and chemical and microbiological $\mathrm{Fe}$ (II) and sulfide oxidation causing rhizospheric acidification during the day; thereby, representing a shift in $\mathrm{P}$ sources over a diurnal cycle.

\section{MATERIALS AND METHODS}

Experimental Setup and Study Site. Seagrass specimens of Cymodocea serrulata (R.Br.) Asch. \& Magnus and carbonaterich, tropical marine sediment were collected at Green Island,
Cairns, Australia ( $16^{\circ} 45^{\prime} 26.244^{\prime \prime}$ S; $145^{\circ} 58^{\prime} 25.7376^{\prime \prime}$ E). Prior to experiments, the sediment was sieved to obtain the $<1$ $\mathrm{mm}$ grain size fraction excluding any larger in-fauna, while maintaining essential nutrients, buffering salts and microbes. Seagrass specimens were gently uprooted and transplanted into the sieved sediment within narrow experimental chambers submerged in $20 \mathrm{~L}$ aquariums (temperature of $28^{\circ} \mathrm{C}$, salinity $=$ 30) (Figure S1). Halogen lamps (Philips Incandescent $230 \mathrm{~V}$ PAR38 80W) illuminated the leaf canopy with a photon irradiance (PAR, $400-700 \mathrm{~nm}$ ) of $\sim 500 \mu \mathrm{mol}$ photons $\mathrm{m}^{-2} \mathrm{~s}^{-1}$ (resembling natural mid-day conditions at the study site), as measured with a spherical quantum sensor (US-SQD/L, Walz $\mathrm{GmbH}$, Germany) connected to a calibrated quantum irradiance meter (ULM-500, Walz GmbH, Germany). Water movement and aeration were provided by submerged waterand air-pumps, respectively.

Diffusive gradients in thin films (DGT) gels for imaging of sulfide and phosphate distributions were positioned at the backwall of the experimental chambers and were separated from the sediment/below-ground seagrass biomass by a fine mesh (plankton mesh DIN 100-60, mesh size $60 \mu \mathrm{m}$, thickness of $50 \mu \mathrm{m})$, to allow for gel deployment and sampling without disturbing the sediment. Multi-ion gels were covered with a Whatman Nucleopore membrane (pore size $0.2 \mu \mathrm{m}$, thickness $10 \mu \mathrm{m})$ and positioned in direct contact with the sediment. Planar optical sensor foils for $\mathrm{pH}$ and $\mathrm{O}_{2}$ imaging were fixed onto the transparent aquarium wall (Notes $\mathrm{S} 1$ and Figure $\mathrm{S} 1$ ).

Seagrass specimens were positioned in the experimental chamber ensuring good contact between the below-ground biomass and the optodes or the DGT gels on the opposite side of the investigated roots, before addition of sieved natural marine sediment from the sampling site (Notes S1).

In situ measurements of the natural dynamics and concentrations of sulfide within the investigated seagrass meadow were obtained by deploying sulfide-sensitive gels mounted in commercial DGT samplers (DGT Research Ltd., www.dgtresearch.com) in the sediment over diurnal cycles (Figure S2). For day-time sulfide measurements, the gel probes were deployed in the seagrass meadow at sunrise and retrieved at sunset, and vice versa for the night-time sulfide measurements, resulting in a DGT exposure period of $\sim 12 \mathrm{~h}$ for both day- and night-time deployments.

Ratiometric Imaging of $\mathrm{O}_{2}$ and $\mathrm{pH}$ Distribution in the Seagrass Rhizosphere. We used planar optodes for imaging the distribution of $\mathrm{O}_{2}$ and $\mathrm{pH}$ around the below-ground seagrass biomass. A detailed description of $\mathrm{O}_{2}$ and $\mathrm{pH}$ planar optode preparation and calibration is given in the Supporting Information (Notes S1). A ratiometric RGB camera setup was used for $\mathrm{O}_{2}$ imaging ${ }^{35}$ with a SLR camera (EOS 1000D, Canon, Japan) equipped with a macro objective lens (Macro 100 f2,8 D, Tokina, Japan), a $530 \mathrm{~nm}$ long-pass filter (Uqgoptics.com), and an additional plastic filter (\#10 medium yellow; leefilters. com) positioned in front of the long-pass filter to reduce the background fluorescence. A $455 \mathrm{~nm}$ multichip LED (LedEngin Inc., RS Components Ltd., Corby, UK) combined with a bandpass filter was used for excitation of the $\mathrm{O}_{2}$ planar optode. The LED was powered by a USB-controlled LED driver unit (imaging.fish-n-chips.de). Image acquisition and control of the SLR and LED were done with the software look@RGB (imaging.fish-n-chips.de).

A similar ratiometric approach was chosen for $\mathrm{pH}$ imaging ${ }^{36}$ using a 2-CCD multispectral camera (JAI AD-080 GE; jai.com) equipped with a video objective lens (1.4/23 CCTV-LENS 


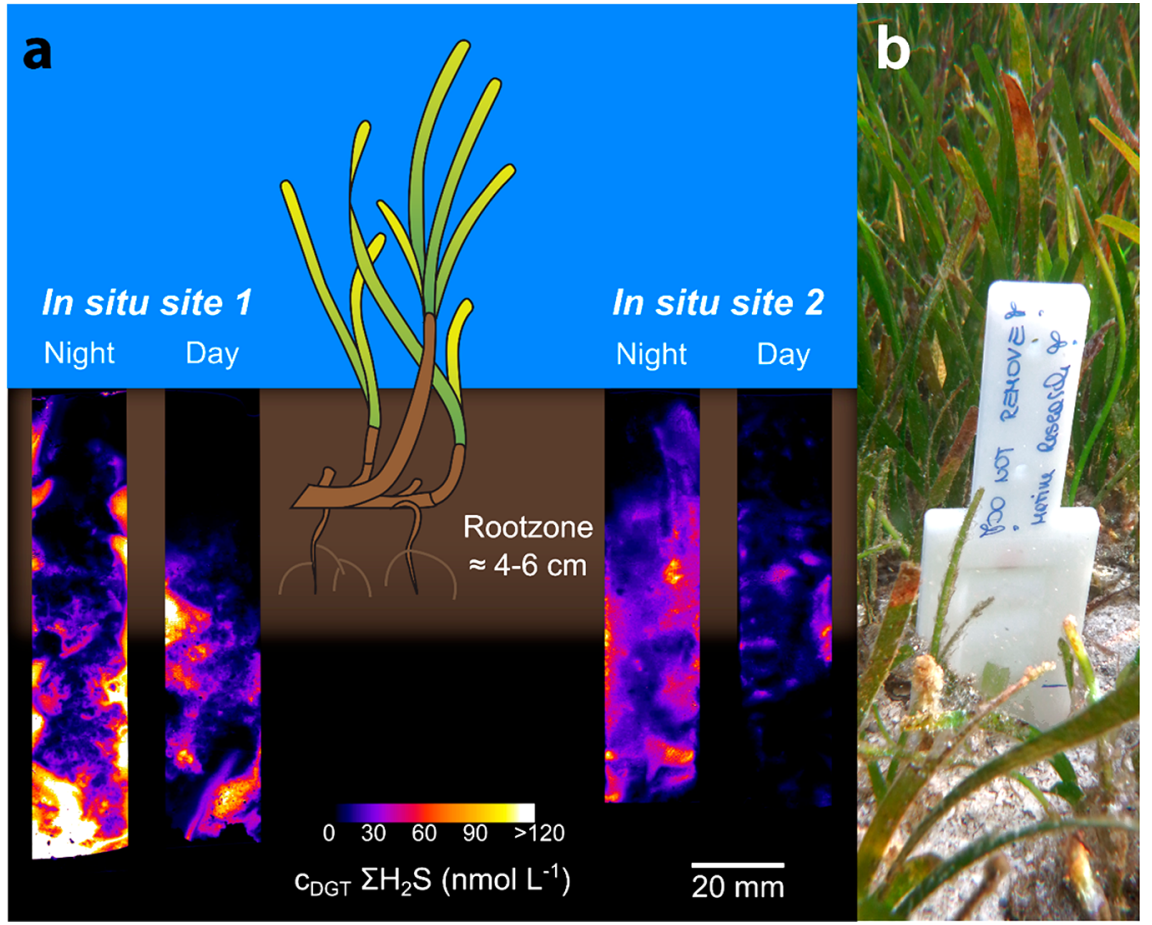

Figure 1. (a) In situ distribution of sulfide as determined with sulfide sensitive Agl DGT gel probes during light (photon irradiance of $500 \mu$ mol photons $\mathrm{m}^{-2} \mathrm{~s}^{-1}$ ) and dark conditions in a sediment colonised by the tropical seagrass species Cymodocea rotundata, Cymodocea serrulata, Halodule uninervis, and Syringodium isoetifolium. (b) The width of all deployed DGT gels was $18 \mathrm{~mm}$. Acquired images were color-coded with a color scale depicting the sediment sulfide concentration.

400-1000 nm; schneiderkreuznach.com) mounted with a 460 $\mathrm{nm}$ long-pass filter (schneiderkreuznach.com) and an additional plastic filter (\#10 medium yellow; leefilters.com). The $\mathrm{pH}$ planar optode was excited with a high-power $405 \mathrm{~nm}$ LED (LedEngin; rs-online.com) with a custom-built LED trigger (National Instruments USB 6008). Image acquisition and triggering of the LED were done via custom-made software (bioras.com).

Acquired RGB color images were split into the red, green, and blue channels and analyzed using the software Image (rsbweb.nih.gov/ij/) (Notes $\mathrm{S} 1$ and Figure S3). For $\mathrm{O}_{2}$ concentration images, the red channel $\left(\mathrm{O}_{2}\right.$ sensitive emission of the indicator dye) and green channel (emission of the inert reference dye) of the color images were divided using the ImageJ plugin Ratio Plus (ratio = red/green). Afterwards, the obtained ratio image was fitted to a previously obtained calibration curve (described in Figure S4) using the Curve Fitting tool of Image (exponential decay function). For $\mathrm{pH}$ images, the red channel ( $\mathrm{pH}$ sensitive emission of the indicator dye) and the blue channel (emission of the reference dye) of the images were divided using the ImageJ plugin Ratio Plus $($ ratio $=$ red/blue $)$. Subsequently, the obtained ratio image was fitted with a previously obtained calibration curve (described in Figure S4) using a linear fit within the boundaries $\left(\mathrm{p} K_{\mathrm{a}} \pm 1 \mathrm{pH}\right.$ units). Calibrated $\mathrm{O}_{2}$ concentration and $\mathrm{pH}$ images were further analyzed in ImageJ.

Gel-Based Rhizospheric Sulfide, Phosphate, Fe(II), and $\mathrm{Ca}^{2+}$ Determination. Here, only a brief summary on gel-based imaging and calibration procedures is given (see further details in the Notes S1).

Single-Element Mapping of Sulfide and Phosphate. Analyte-sensitive gels (precipitated $\mathrm{Zr}$-oxide gels for phosphate and AgI gels for sulfide; calibration curves are shown in Figure
S5 and S6) were deployed into the experimental microcosms for $12 \mathrm{~h}$. After gel retrieval, the phosphate-collecting gels were stained with a molybdate blue reagent, and subjected to computer imaging densitometric (CID) analysis. ${ }^{37}$ No staining step was necessary for the sulfide bound to the AgI gels, as the formed $\mathrm{Ag}_{2} \mathrm{~S}$ was black, while the AgI background was pale white. ${ }^{38}$ The CID of the retrieved gels was done with a flatbed scanner (Canon MG2460, Canon, Japan). The retrieved sulfide and phosphate sensitive gels were fixed flat between two transparent PET sheets to avoid direct contact with the scanner and were scanned at a resolution of $600 \mathrm{dpi}$. Acquired images were further processed using ImageJ and Origin Pro (OriginLab Corp., USA).

Simultaneous Imaging of Phosphate, $\mathrm{Fe}(\mathrm{II})$ and $\mathrm{Ca}^{2+}$. $\mathrm{Zr}$ oxide-SPR-IDA gels for simultaneous sampling of phosphate, $\mathrm{Fe}(\mathrm{II})$ and $\mathrm{Ca}^{2+39}$ were deployed into the experimental mesocosms for $24 \mathrm{~h}$. After deployment, the retrieved $\mathrm{Zr}$ oxide-SPR-IDA gels were dried, mounted onto glass slides and subjected to LA-ICPMS analysis on a UP 193-FX laser ablation instrument (ESI, NWR division) coupled to a Nexion 350D ICPMS (PerkinElmer). Count rates were recorded for several isotopes including ${ }^{13} \mathrm{C},{ }^{31} \mathrm{P},{ }^{44} \mathrm{Ca}$, and ${ }^{57} \mathrm{Fe}$, where ${ }^{13} \mathrm{C}$ was used as internal normalization standard. Gels were imaged at horizontal spatial resolutions of $96 \mu \mathrm{m}$ (Figure 4, dark; Figure S9, light) and $113 \mu \mathrm{m}$ (Figure 4, light; Figure S9, dark), and a vertical spatial resolution of $400 \mu \mathrm{m}$. Chemical images were generated and arranged using Microsoft Excel (Microsoft Corp., Redmond, USA), ImageJ, Systat SigmaPlot (Systat Software Inc., San Jose, USA), Adobe Photoshop, and Adobe InDesign (Adobe Corp., San Jose, USA). 


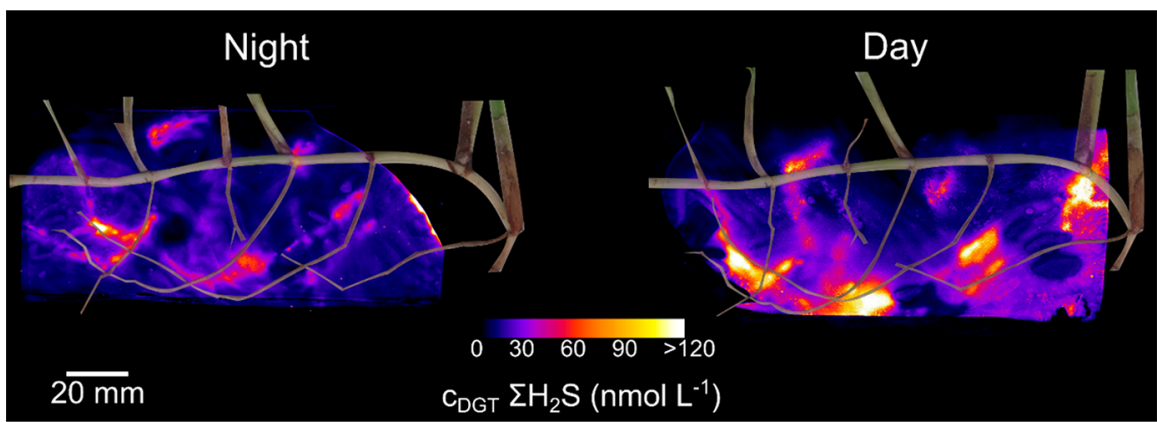

Figure 2. Distribution of sulfide concentrations in the rhizosphere of Cymodocea serrulata during light (photon irradiance of $500 \mu$ mol photons $\mathrm{m}^{-2}$ $\mathrm{s}^{-1}$ ) and dark conditions. The sulfide concentrations were determined with Agl DGT gel probes sensitive to sulfide. Images were color-coded with a color scale depicting the sediment sulfide concentration.

\section{RESULTS AND DISCUSSION}

Our results show that the tropical seagrass Cymodocea rotundata is able to mobilize phosphorus and iron around its roots in oligotrophic, carbonate-rich sediments by protolytic dissolution of Ca-phosphates, as well as, by reductive dissolution of insoluble Fe(III)-oxyhydroxides. Below, we describe in detail the multiple biogeochemical pathways resulting in nutrient solubilization in the seagrass rhizosphere.

In Situ Sulfide Distribution and Dynamics. In situ sulfide measurements in carbonate-rich sediments vegetated by tropical seagrasses (Cymodocea rotundata, Cymodocea serrulata, Halodule uninervis, and Syringodium isoetifolium) revealed a net downward movement of the sediment sulfide front during daytime and a concomitant reduction in sulfide concentration within the upper $\sim 10 \mathrm{~cm}$ of the sediments (Figure 1a). Enhanced re-oxidation of sediment-produced sulfide during day-time is caused by higher ROL from the below-ground seagrass tissue, which is driven by high $\mathrm{O}_{2}$ partial pressure $\left(p \mathrm{O}_{2}\right)$ in the photosynthetic leaves enhancing gaseous $\mathrm{O}_{2}$ transport to the rhizosphere. ${ }^{17,20,40}$ During night-time, seagrasses are completely dependent on passive $\mathrm{O}_{2}$ influx into the leaves from the surrounding water-column, ${ }^{17,33}$ leading to diminished ROL, which caused the sulfide front to migrate toward the water/sediment interface increasing the tissue exposure to phytotoxic $\mathrm{H}_{2} \mathrm{~S}$ (Figure 1a).

Mapping of Rhizospheric Sulfide Concentrations. Microniches at the below-ground tissue/sediment interface exhibited distinct low-sulfide microzones around the root/ shoot junctions of the seagrasses in the uppermost part of the rhizosphere, as well as around some of the deeper-lying roottips, and these oxidized zones markedly expanded during light exposure of the leaf canopy (Figure 2). Other microniches around mature parts of the roots exhibited high sulfide concentrations indicative of local stimulation of sulfate reduction, probably owed to root/rhizome exudation of DOC during photosynthesis ${ }^{30,31,41}$ and/or depletion of electron acceptors other than sulfate in the absence of ROL-driven reoxidation processes (Figure 2). Such microheterogeneity in the rhizospheric sulfide concentration and distribution can be explained by a high ROL from the root/shoot junctions and apical root meristems of the investigated tropical seagrass Cymodocea serrulata (Figure S7; showing seagrass-generated rhizospheric $\mathrm{O}_{2}$ distributions during light and dark conditions) leading to local sulfide oxidation, which is similar to ROL in other seagrass species. ${ }^{17,20,24}$ Seagrass-derived sulfide oxidation furthermore resulted in rhizospheric proton formation and thus localized acidification of the immediate rhizosphere (Figure 3), as previously shown for the temperate seagrass species Zostera muelleri and Zostera marina. ${ }^{17,18}$

pH Heterogeneity. Planar optode imaging demonstrated distinct rhizospheric $\mathrm{pH}$ heterogeneity around below-ground tissues of Cymodocea serrulata. Low-pH microniches (as compared to the bulk sediment) were found at the meristematic region of the rhizome, that is, the basal leaf

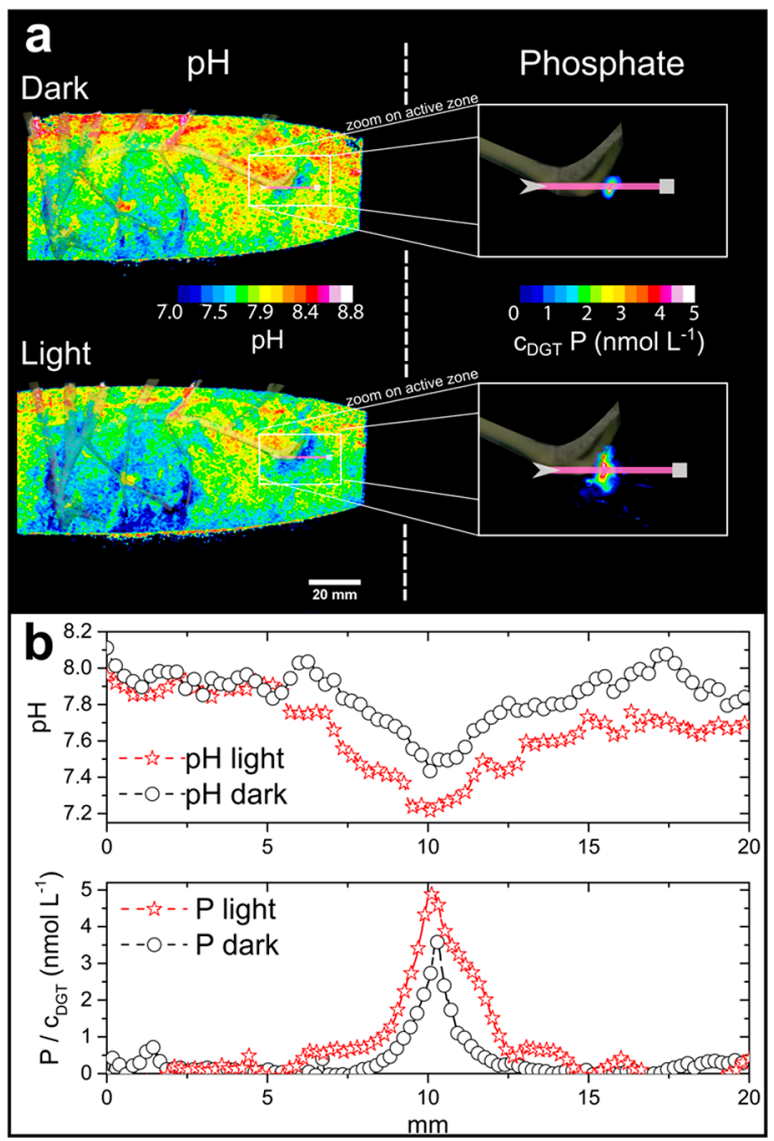

Figure 3. (a) Rhizospheric $\mathrm{pH}$ and phosphorus distributions in carbonate-rich sediment around the tropical seagrass Cymodocea serrulata during light (photon irradiance of $500 \mu \mathrm{mol}$ photons $\mathrm{m}^{-2}$ $\mathrm{s}^{-1}$ ) and dark conditions. The enlarged plot focuses on the basal leaf meristem area, that is, the meristematic region of the rhizome. (b) Rhizospheric $\mathrm{pH}$ and phosphate concentrations during light and dark conditions as extracted along the cross-tissue line profiles shown in (a). Images were color-coded with color scales depicting the sediment $\mathrm{pH}$ and phosphate concentrations, respectively. 


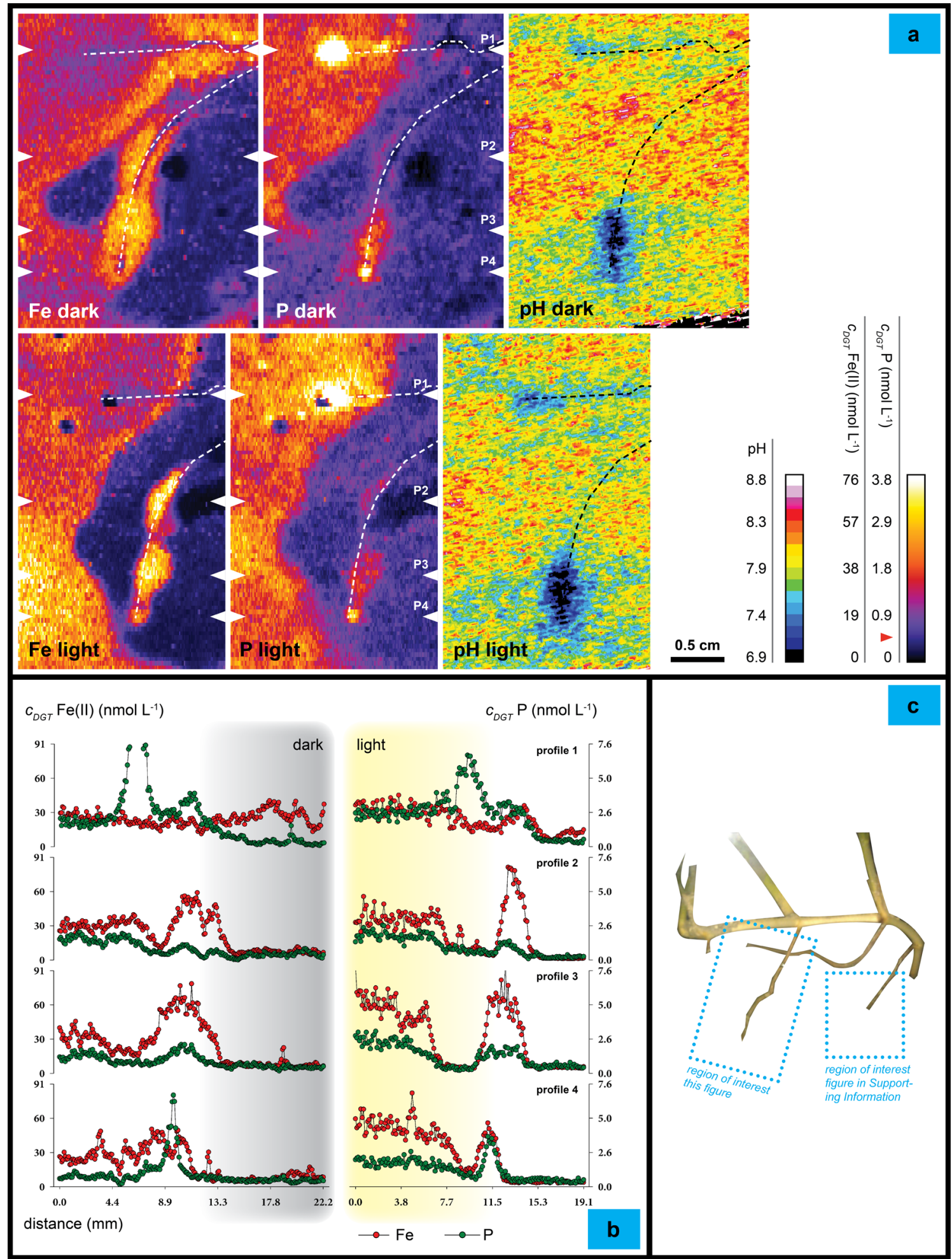

Figure 4. Co-distributions of seagrass-mediated rhizospheric phosphorus and $\mathrm{Fe}(\mathrm{II})$ solubilization coupled to plant-generated $\mathrm{pH}$ microheterogeneity at the root/sediment interface during light (photon irradiance of $500 \mu \mathrm{mol}$ photons $\mathrm{m}^{-2} \mathrm{~s}^{-1}$ ) and dark conditions in carbonate-rich marine sediment inhabited by the tropical seagrass Cymodocea serrulata. (a) Rhizospheric $\mathrm{pH}, \mathrm{Fe}$ (II) and phosphorus concentrations within the selected region of interest, as shown on the provided illustration of the below-ground plant tissue structure (c). The dotted lines on the chemical images show the position of the roots. (b) Concentration profiles (P1-4) extracted at the positions indicated by the white arrows along the figure edge, showing cross tissue $\mathrm{Fe}(\mathrm{II})$ and phosphorus concentrations during light and dark conditions. All images were color-coded, where the color scales depict the sediment $\mathrm{pH}, \mathrm{Fe}$ (II) and phosphorus concentrations, respectively. The red arrow on the phosphorus scale bar indicates the method detection limit (MDL) for the applied phosphorus sensitive multi-ion gel (Zr-oxide-SPR-IDA). No such arrow is shown for Fe as the MDL was negligibly small in this case. 
meristem, and around the roots and older parts of the rhizome, with light exposure of the leaf canopy leading to stronger acidification (Figures $3 \mathrm{a}$ and S8) than during dark periods. Other microniches with high $\mathrm{pH}$ were observed around the first internode of the rhizome adjacent to the basal leaf meristem, as well as around the prophyllums, that is, single leaves originating from the root/shoot junctions (Figure 3a). Rhizospheric $\mathrm{pH}$ microheterogeneity was caused by localized ROL-driven sulfide oxidation along with the precipitation of $\mathrm{Fe}$ (III) oxyhydroxides both causing acidification, and potentially also by DOC leakage stimulating proton-consuming sulfate reduction in line with previous findings in the temperate seagrass species Zostera marina. ${ }^{18}$ Seagrass-derived low $\mathrm{pH}$ microniches may have been further supported by secretion of organic acids from the roots, ${ }^{16}$ although this can lead to both a direct reduction in rhizosphere $\mathrm{pH}$ and an indirect increase in $\mathrm{pH}$ via stimulation of SRB.

Phosphorus and Iron Solubilization. The local reduction in rhizosphere $\mathrm{pH}$ resulted in pronounced phosphorus solubilization at the basal leaf meristem, caused by the acid dissolution of calcium phosphates such as carbonate-fluorapatite (Figure 3a), where a seagrass-mediated reduction in rhizosphere $\mathrm{pH}$ of $\sim 0.8 \mathrm{pH}$ units at the basal leaf meristem correlated with a localized $\sim 20$-fold increase in porewater phosphorus availability (Figure $3 \mathrm{~b}$ ).

Imaging of dissolved $\mathrm{Fe}$ (II) and phosphorus distributions in the rhizosphere during light and dark conditions demonstrated combined sulfide- and acidification-induced phosphorus and iron solubilization in the carbonate-rich sediments around seagrass roots, especially around the root tips (Figure 4; Figure S9). At the tip of the root originating from the fourth root/ shoot junction (Figure 4c), the seagrass-mediated phosphorus solubilization was dominated by low $\mathrm{pH}$-induced dissolution of calcium phosphates and thus the release of calcium-bound phosphorus into the porewater (Figure $4 \mathrm{a}$ and $\mathrm{b}$; Figure S10, showing calcium phosphate dissolution). Around the root originating from the third root/shoot junction (Figure 4c), the seagrass-driven phosphorus solubilization was due to combined sulfide- and low $\mathrm{pH}$-induced phosphorus release owed to reduction of insoluble $\mathrm{Fe}$ (III) oxyhydroxides, as well as calcium phosphate dissolution (Figure $4 \mathrm{a}$ and $\mathrm{b}$; Figure S10). The phosphorus mobilization around roots caused an up to $\sim 10$ fold increase in the rhizospheric phosphorus availability (Figures $4 a$ and $b$ and 59) and thus presents a major source for satisfying the plant's $\mathrm{P}$ demand.

Tropical seagrasses roughly require $60-175 \mu \mathrm{mol} \mathrm{P} \mathrm{m} \mathrm{m}^{-2} \mathrm{~d}^{-1}$ (based on estimates reported by Fourqurean et al. ${ }^{42}$ and Jensen et al., and assuming a 1:1 ratio between the above- to belowground biomass and similar \% P assimilation in the above- and below-ground tissues). DGT measurement cannot be directly interpreted as an actual porewater concentration (see detailed discussion in the Supporting Information ${ }^{43}$ ), however, Udy et al. $^{44}$ reported porewater phosphate concentrations ranging from $0.6-1.7 \mu \mathrm{M}$ in sediments around Green Island, which is similar to concentrations reported from seagrass meadows in Florida Bay, USA $\left(0.5\right.$ to $\left.3 \mu \mathrm{M}^{42}\right)$ and the Bahamas $\left(1.5 \mu \mathrm{M}^{45}\right)$. At Green Island, it would make sense to use the lower end of the phosphate concentration range reported (i.e., $0.6 \mu \mathrm{M}$ ), as these measurements of sediment nutrients were taken less than a decade after tertiary treatment of wastewater from the resort at Green Island was installed. ${ }^{44}$ Assuming a porewater phosphate concentration of $0.6 \mu \mathrm{M}$ or $60 \mu \mathrm{mol} \mathrm{m}^{-2}$ (calculated from a rhizosphere depth of $10 \mathrm{~cm}$ ) in the sediments around
Green Island, the seagrass-mediated nutrient mobilization mechanisms would enhance the rhizosphere phosphate concentration to $\sim 600-1200 \mu \mathrm{mol} \mathrm{m}{ }^{-2}$. The actual porewater phosphate concentration at Green Island (i.e. $60 \mu \mathrm{mol} \mathrm{m}{ }^{-2}$ ) would thus be consumed within 1 day, if not renewed or mobilized. When taking the seagrass-mediated phosphorus nutrient mobilization mechanisms into account, the increased porewater phosphate concentration alone would support seagrass growth for up to 10-20 days. However, P pools adsorbed to carbonate sediments are much larger, estimated to $\sim 20 \mathrm{mmol} \mathrm{m}^{-2}$ by Jensen et al., ${ }^{8}$ which would support tropical seagrass growth for up to $\sim 1$ year, if not renewed.

We also found a pronounced increase in dissolved $\mathrm{Fe}$ (II) around the roots of Cymodocea serrulata. This Fe(II) solubilization was caused by reductive dissolution of $\mathrm{Fe}$ (III) oxyhydroxides and resulted in a $\sim 10$-fold increase in the rhizospheric $\mathrm{Fe}(\mathrm{II})$ concentration (Figure 4a,b; Figure S9). Such enhanced $\mathrm{Fe}$ (II) availability around roots (Figure 4a,b) could help alleviate potential Fe deficiency in leaves. ${ }^{14}$ The slightly lower phosphate concentration around roots in light as compared to darkness (Figure 4) was probably due to a higher phosphate absorption rate of seagrass rhizome and roots in the light. ${ }^{46}$ In general, we showed that the nutrient mobilization capacity of the tropical seagrass Cymodocea serrulata increased in the light owing to enhanced ROL and potentially also due to root/rhizome exudation of DOC and organic acids (Figure 3; Figure S7 and S9).

The high phosphorus and iron mobilization at plant/ sediment interfaces as driven by tropical seagrasses colonizing carbonate-rich sediments could potentially be further supported by $\mathrm{Fe}(\mathrm{III})$-reducing and/or phosphorus-solubilizing bacteria if present in the surrounding sediment (e.g., refs 10 and 47). Direct microbial $\mathrm{Fe}(\mathrm{III})$ reduction would lead to further formation of dissolved $\mathrm{Fe}$ (II) and phosphate in the adjacent sediment, precipitating sulfide diffusing from anoxic, sulphidic sediment zones as $\mathrm{FeS},{ }^{48}$ and thus functioning as an additional protection mechanism against $\mathrm{H}_{2} \mathrm{~S}$ accumulation and intrusion in the rhizosphere. However, direct microbial reduction of $\mathrm{Fe}$ (III) would preferably occur in the anoxic microniches of the seagrass rhizosphere with low $\mathrm{H}_{2} \mathrm{~S}$ production ${ }^{48}$ and not at the root/shot junctions and the root-tips that are generally considered oxic microenvironments. ${ }^{17,19,20,24}$ Nevertheless, this potential additional microbe-driven source of nutrients for tropical seagrasses deserves further attention in future studies.

Tropical seagrasses can thus solubilize phosphorus and iron around their below-ground biomass in carbonate-rich sediments via multiple biogeochemical pathways (Figure 5). Seagrass-derived rhizospheric phosphorus mobilization was mainly the result of a low $\mathrm{pH}$-induced dissolution of sediment calcium phosphates combined with a sulfide-induced reduction of $\mathrm{Fe}$ (III) oxyhydroxides, as well as direct microbial $\mathrm{Fe}(\mathrm{III})$ reduction, leading to local enhancement of dissolved $\mathrm{Fe}$ (II) and release of $\mathrm{Fe}(\mathrm{III})$-bound phosphate. Moreover, our results indicate that diurnal cycles in rates of ROL resulted in relative changes in the phosphate and $\mathrm{Fe}$ (II) sources to the seagrass, where microbial $\mathrm{Fe}$ (III) and sulfate reduction leading to reductive dissolution of $\mathrm{Fe}(\mathrm{III})$ oxyhydroxides and thus phosphate and $\mathrm{Fe}$ (II) co-solubilization dominated in darkness. Chemical and microbial $\mathrm{Fe}$ (II) and sulfide oxidation resulting in rhizospheric acidification and protolytic dissolution of Caphosphates, that is, solubilization of phosphate, seemed to be dominating in the light. Phosphorus and iron are key limiting 


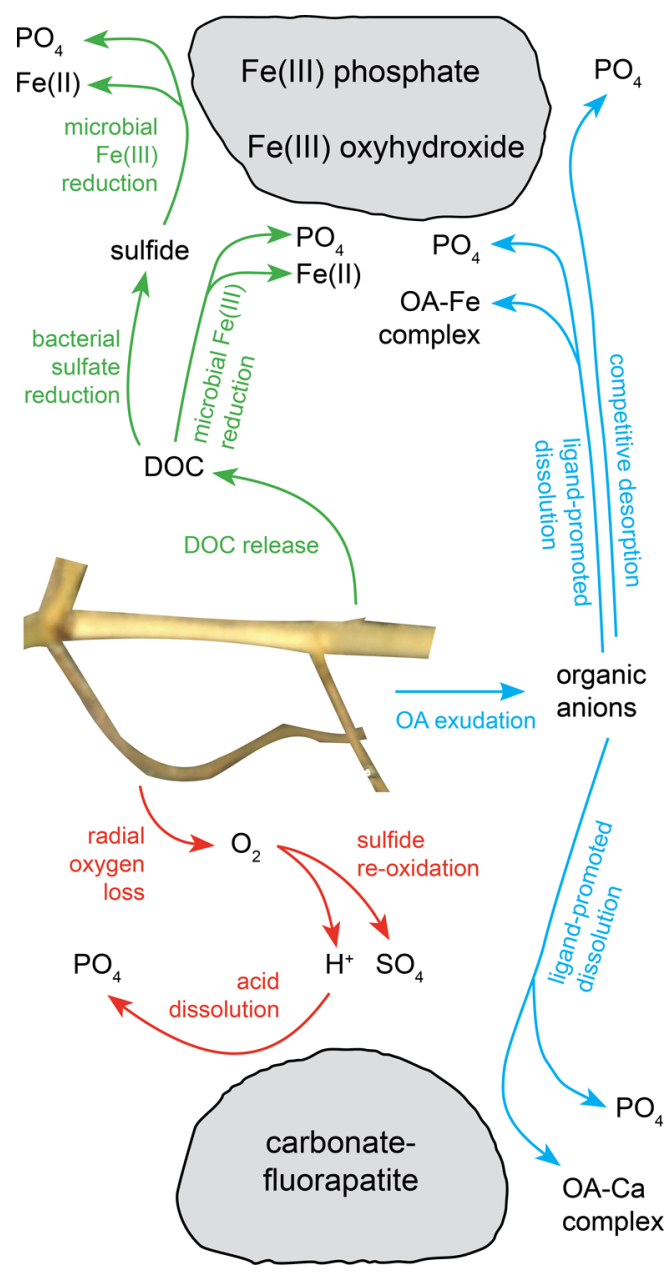

Figure 5. Conceptual diagram of seagrass-derived rhizospheric phosphorus and iron mobilization mechanisms in carbonate-rich sediments. Showing (i) protolytic dissolution of Ca-phosphates, (ii) reductive dissolution of insoluble $\mathrm{Fe}(\mathrm{III})$-oxyhydroxides, and (iii) ligand-promoted dissolution and competitive desorption induced by exuded organic anions.

nutrients in tropical environments, including tropical seagrass meadows, owing to their high insolubility in the sediment. Our experimental demonstration of seagrass-driven phosphorus and iron mobilization mechanisms in carbonate-rich sediments now explains how seagrasses can thrive in oligotrophic, tropical waters.

\section{ASSOCIATED CONTENT}

\section{S Supporting Information}

The Supporting Information is available free of charge on the ACS Publications website at DOI: 10.1021/acs.est.7b03878.

Supporting details and methods; schematic drawing of applied experimental chamber and seawater reservoir; deployment of sulfide sensitive DGT gels in situ; chemical structures of indicator and reference dyes; calibration plots of planar $\mathrm{O}_{2}$ and $\mathrm{pH}$ optodes; calibration plot of sulfide-binding Agl gel; calibration plot of the $\mathrm{PO}_{4}{ }^{3-}$ binding precipitated $\mathrm{Zr}$-oxide gel; distribution and dynamics of $\mathrm{O}_{2}$ concentration within the rhizosphere of the tropical seagrass Cymodocea serrulata during dark and light conditions; $\mathrm{pH}$ heterogeneity and dynamics within the rhizosphere of the tropical seagrass
Cymodocea serrulata during dark and light conditions; $\mathrm{Fe}(\mathrm{II})$, phosphorus, and $\mathrm{pH}$ distribution in the rhizosphere of the tropical seagrass species Cymodocea serrulata during dark and light conditions; distribution and dynamics of calcium ( $\mathrm{Ca}$ ) within the rhizosphere of the tropical seagrass Cymodocea serrulata during dark and light conditions (PDF)

\section{AUTHOR INFORMATION}

\section{Corresponding Authors}

*E-mail: mkuhl@bio.ku.dk.

*E-mail: jakob.santner@boku.ac.at.

\section{ORCID}

Kasper Elgetti Brodersen: 0000-0001-9010-1179

\section{Author Contributions}

K.E.B., K.K., and M.M. contributed equally to this work and share the first authorship of this paper. K.E.B., K.K., J.S., M.M., P.J.R., and M.K. planned and designed the study. K.E.B., K.K, and M.M. performed the experiments. K.E.B., K.K., M.M., and J.S. processed gels and experimental data with inputs from M.K. K.E.B., K.K., J.S., M.M., and M.K. analyzed the data. K.E.B. wrote the manuscript with editorial inputs from all coauthors. K.K., M.M., J.S., and K.E.B. prepared the Supporting Information with editorial inputs from M.K. and P.J.R.

\section{Notes}

The authors declare no competing financial interest.

\section{ACKNOWLEDGMENTS}

We thank Paul York, James Cook University Cairns (JCU) for field guidance and assistance during seagrass sampling, Michael Rasheed (JCU) for help with seagrass identification, Egil Nielsen (University of Copenhagen) for manufacturing experimental chambers, Joey Crosswell (University of Technology Sydney) for manufacturing LED lamps, Christoph Hoefer (University of Natural Resources and Life Sciences, Vienna) for help with DGT gel preparation and analysis, and Sergey M. Borisov (Graz University of Technology) for help with optical sensor development. The study was funded by research grants from the Danish Council for Independent Research I Natural Sciences (Sapere-Aude Advanced grant, MK); the Carlsberg Foundation (CF16-0899) (KEB); the Villum Foundation (MK, KK); the Australian Research Council (ARC Linkage, LP110200454) (MK, PJR); the Augustinus Foundation (KEB); the EU Erasmus+ exchange program (MM); the Austrian Science Fund (FWF): P23798-B16, P27571-BBL (JS); and the province of Lower Austria (P27571-BBL) (JS).

\section{REFERENCES}

(1) Costanza, R.; d'Arge, R.; de Groot, R.; Farber, S.; Grasso, M.; Hannon, B.; Sutton, P.; et al. The value of the world's ecosystem services and natural capital. Nature 1997, 387, 253-260.

(2) Waycott, M.; Duarte, C. M.; Carruthers, T. J. B.; Orth, R. J.; Dennison, W. C.; Olyarnik, S.; Williams, S. L.; et al. Accelerating loss of seagrasses across the globe threatens coastal ecosystems. Proc. Natl. Acad. Sci. U. S. A. 2009, 106, 12377-12381.

(3) Harborne, A. R.; Mumby, P. J.; Micheli, F.; Perry, C. T.; Dahlgren, C. P.; Holmes, K. E.; Brumbaugh, D. R. The functional value of Caribbean coral reef, seagrass and mangrove habitats to ecosystem processes. Adv. Mar. Biol. 2006, 50, 57-189.

(4) Duarte, C. M.; Middelburg, J. J.; Caraco, N. Major role of marine vegetation on the oceanic carbon cycle. Biogeosciences 2005, 2, 1-8.

(5) Koch, E. W.; Barbier, E. B.; Silliman, B. R.; Reed, D. J.; Perillo, G. M. E.; Hacker, S. D.; Wolanski, E.; et al. Non-linearity in ecosystem 
services: Temporal and spatial variability in coastal protection. Frontiers in Ecology and the Environment 2009, 7, 29-37.

(6) Short, F.; Dennison, W. C.; Capone, D. G. Phosphorus-limited growth of the tropical seagrass Syringodium filiforme in carbonate sediments. Mar. Ecol.: Prog. Ser. 1990, 62, 169-174.

(7) Fourqurean, J. W.; Zieman, J. C.; Powell, G. V. N. Phosphorus limitation of primary production in Florida Bay: Evidence from C:N:P ratios of the dominant seagrass Thalassia testudinum. Limnol. Oceanogr. 1992, 37, 162-171.

(8) Jensen, H. S.; McGlathery, K. J.; Marino, R.; Howarth, R. W. Forms and availability of sediment phosphorus in carbonate sand of Bermuda seagrass beds. Limnol. Oceanogr. 1998, 43, 799-810.

(9) Nielsen, O. I.; Koch, M. S.; Madden, C. J. Inorganic phosphorus uptake in a carbonate dominated seagrass ecosystem. Estuaries Coasts 2007, 30 (5), 827-839.

(10) Pagès, A.; Welsh, D. T.; Robertson, D.; Panther, J. G.; Schäfer, J.; Tomlinson, R. B.; Teasdale, P. R. Diurnal shifts in co-distributions of sulfide and iron(II) and profiles of phosphate and ammonium in the rhizosphere of Zostera capricorni. Estuarine, Coastal Shelf Sci. 2012, 115, 282-290.

(11) Raghothama, K. G. Phosphate acquisition. Annu. Rev. Plant Physiol. Plant Mol. Biol. 1999, 50 (1), 665-693.

(12) McRoy, C. P.; Barsdate, R. J.; Nebert, M. Phosphorus cycling in an eelgrass (Zostera marina L.) ecosystem. Limnol. Oceanogr. 1972, 17, $58-67$.

(13) Larkum, A. W. D.; Orth, R. J.; Duarte, C. M. Seagrasses: Biology, Ecology and Conservation; Springer, Berlin, 2006.

(14) Duarte, C. M.; Merino, M.; Gallegos, M. Evidence of iron deficiency in seagrasses growing above carbonate sediments. Limnol. Oceanogr. 1995, 40, 1153-1158.

(15) York, P. H.; Smith, T. M.; Coles, R. G.; McKenna, S. A.; Connolly, R. M.; Irving, A. D.; Whitehead, S.; et al. Identifying knowledge gaps in seagrass research and management: an Australian perspective. Mar. Environ. Res. 2017, 127, 163-172.

(16) Long, M. H.; McGlathery, K. J.; Zieman, J. C.; Berg, P. The role of organic acid exudates in liberating phosphorus from seagrassvegetated carbonate sediments. Limnol. Oceanogr. 2008, 53, 26162626.

(17) Brodersen, K. E.; Nielsen, D. A.; Ralph, P. J.; Kühl, M. Oxic microshield and local $\mathrm{pH}$ enhancement protects Zostera muelleri from sediment derived hydrogen sulphide. New Phytol. 2015, 205, 12641276.

(18) Elgetti Brodersen, K.; Koren, K.; Lichtenberg, M.; Kühl, M. Nanoparticle-based measurements of $\mathrm{pH}$ and $\mathrm{O}_{2}$ dynamics in the rhizosphere of Zostera marina L.: effects of temperature elevation and light-dark transitions. Plant, Cell Environ. 2016, 39, 1619-1630.

(19) Pedersen, O.; Borum, J.; Duarte, C. M.; Fortes, M. D. Oxygen dynamics in the rhizosphere of Cymodocea rotundata. Mar. Ecol.: Prog. Ser. 1998, 169, 283-288.

(20) Koren, K.; Brodersen, K. E.; Jakobsen, S. L.; Kühl, M. Optical sensor nanoparticles in artificial sediments - A new tool to visualize $\mathrm{O}_{2}$ dynamics around the rhizome and roots of seagrasses. Environ. Sci. Technol. 2015, 49, 2286-2292.

(21) Barnabas, A. D. Casparian band-like structures in the root hypodermis of some aquatic angiosperms. Aquat. Bot. 1996, 55, 217225.

(22) Colmer, T. D. Long-distance transport of gases in plants: a perspective on internal aeration and radial oxygen loss from roots. Plant, Cell Environ. 2003, 26, 17-36.

(23) Borum, J.; Sand-Jensen, K.; Binzer, T.; Pedersen, O.; Greve, T. M. Oxygen movement in seagrasses. In Seagrasses: Biology, Ecology and Conservation; Larkum, A. W. D., Orth, J. R., Duarte, C. M., Eds.; Springer: Berlin, 2006; pp 255-270.

(24) Jensen, S. I.; Kühl, M.; Glud, R. N.; Jørgensen, L. B.; Priemé, A. Oxic microzones and radial oxygen loss from roots of Zostera marina. Mar. Ecol.: Prog. Ser. 2005, 293, 49-58.

(25) Moriarty, D. J. W.; Iverson, R. L.; Pollard, P. C. Exudation of organic carbon by the seagrass Halodule wrightii Aschers. and its effect on bacterial growth in the sediment. J. Exp. Mar. Biol. Ecol. 1986, 96, $115-126$.

(26) Badri, D. V.; Vivanco, J. M. Regulation and function of root exudates. Plant, Cell Environ. 2009, 32, 666-681.

(27) Welsh, D. T.; Wellsbury, P.; Bourguès, S.; de Wit, R.; Herbert, R. A. Relationship between porewater organic carbon content, sulphate reduction and nitrogen fixation (acetylene reduction) in the rhizosphere of Zostera noltii. Hydrobiologia 1996, 329, 175-183.

(28) Welsh, D. T. Nitrogen fixation in seagrass meadows: Regulation, plant-bacteria interactions and significance to primary productivity. Ecology Letters 2000, 3, 58-71.

(29) Cúcio, C.; Engelen, A. H.; Costa, R.; Muyzer, G. Rhizosphere microbiomes of European seagrasses are selected by the plant, but are not species specific. Front. Microbiol. 2016, 7, 440.

(30) Blaabjerg, V.; Mouritsen, K. N.; Finster, K. Diel cycles of sulphate reduction rates in sediments of a Zostera marina bed (Denmark). Aquat. Microb. Ecol. 1998, 15, 97-102.

(31) Nielsen, L. B.; Finster, K.; Welsh, D. T.; Donelly, A.; Herbert, R. A.; de Wit, R.; Lomstein, B. Sulphate reduction and nitrogen fixation rates associated with roots, rhizomes and sediments from Zostera noltii and Spartina maritima meadows. Environ. Microbiol. 2001, 3, 63-71.

(32) Lamers, L. P.; Govers, L. L.; Janssen, I. C.; Geurts, J. J.; Van der Welle, M. E.; Van Katwijk, M. M.; Smolders, A. J. P.; et al. Sulfide as a soil phytotoxin - a review. Front. Plant Sci. 2013, 4, 268.

(33) Borum, J.; Pedersen, O.; Greve, T. M.; Frankovich, T. A.; Zieman, J. C.; Fourqurean, J. W.; Madden, C. J. The potential role of plant oxygen and sulphide dynamics in die-off events of the tropical seagrass, Thalassia testudinum. J. Ecol. 2005, 93, 148-158.

(34) Brodersen, K. E.; Hammer, K. J.; Schrameyer, V.; Floytrup, A.; Rasheed, M. A.; Ralph, P. J.; Kühl, M.; Pedersen, O. Sediment resuspension and deposition on seagrass leaves impedes internal plant aeration and promotes phytotoxic $\mathrm{H}_{2} \mathrm{~S}$ intrusion. Front. Plant Sci. 2017, 8,657 .

(35) Larsen, M.; Borisov, S. M.; Grunwald, B.; Klimant, I.; Glud, R. $\mathrm{N}$. A simple and inexpensive high resolution color ratiometric planar optode imaging approach: application to oxygen and $\mathrm{pH}$ sensing. Limnol. Oceanogr.: Methods 2011, 9, 348-360.

(36) Moßhammer, M.; Strobl, M.; Kühl, M.; Klimant, I.; Borisov, S. M.; Koren, K. Design and application of an optical sensor for simultaneous imaging of $\mathrm{pH}$ and dissolved $\mathrm{O}_{2}$ with low cross-talk. ACS Sensors 2016, 1, 681-687.

(37) Ding, S.; Wang, Y.; Xu, D.; Zhu, C.; Zhang, C. Gel-based coloration technique for the submillimeter-scale imaging of labile phosphorus in sediments and soils with diffusive gradients in thin films. Environ. Sci. Technol. 2013, 47, 7821-7829.

(38) Teasdale, P. R.; Hayward, S.; Davison, W. In situ, highresolution measurement of dissolved sulfide using diffusive gradients in thin films with computer-imaging densitometry. Anal. Chem. 1999, 71, 2186-2191.

(39) Kreuzeder, A.; Santner, J.; Prohaska, T.; Wenzel, W. W. Gel for simultaneous chemical imaging of anionic and cationic solutes using diffusive gradients in thin films. Anal. Chem. 2013, 85, 12028-12036.

(40) Pedersen, O.; Binzer, T.; Borum, J. Sulphide intrusion in eelgrass (Zostera marina L.). Plant, Cell Environ. 2004, 27, 595-602.

(41) Pollard, P. C.; Moriarty, D. J. W. Organic carbon decomposition, primary and bacterial productivity, and sulphate reduction, in tropical seagrass beds of the Gulf of Carpentaria, Australia. Mar. Ecol.: Prog. Ser. 1991, 69, 149-159.

(42) Fourqurean, J. W.; Zieman, J. C.; Powell, G. V. N. Relationships between porewater nutrients and seagrasses in a subtropical carbonate environment. Marine Biology 1992, 114, 57-65.

(43) Santner, J.; Larsen, M.; Kreuzeder, A.; Glud, R. N. Two decades of chemical imaging of solutes in sediments and soils-a review. Anal. Chim. Acta 2015, 878, 9-42.

(44) Udy, J. W.; Dennison, W. C.; Lee Long, W. J.; McKenzie, L. J. Responses of seagrass to nutrients in the Great Barrier Reef, Australia. Mar. Ecol.: Prog. Ser. 1999, 185, 257-271.

(45) Short, F. T.; Davis, M. W.; Gibson, R. A.; Zimmermann, C. F. Evidence for phosphate limitation in carbonate sediments of the 
seagrass Syringodium filiforme. Estuarine, Coastal Shelf Sci. 1985, 20, 419-430.

(46) McRoy, C. P.; Barsdate, R. J. Phosphate absorption in eelgrass. Limnol. Oceanogr. 1970, 15, 6-13.

(47) Vazquez, P.; Holguín, G.; Puente, M.; Lopez-Cortes, A.; Bashan, Y. Phosphate-solubilizing microorganisms associated with the rhizosphere of mangroves in a semiarid coastal lagoon. Biol. Fertil. Soils 2000, 30, 460-468.

(48) Thamdrup, B.; Fossing, H.; Jørgensen, B. B. Manganese, iron and sulfur cycling in a coastal marine sediment, Aarhus Bay, Denmark. Geochim. Cosmochim. Acta 1994, 58, 5115-5129. 